\title{
DESIGNING CAMTASIA SOFTWARE ASSISTED LEARNING MEDIA TOWARD STUDENTS' MATHEMATICAL COMPREHENSION IN NUMERAL
}

\author{
Setiyani $^{* 1}$, Dian Permana Putri ${ }^{2}$, Derin Prakarsa ${ }^{3}$ \\ 1,2,3 Universtas Swadaya Gunung Djati
}

\section{Article Info \\ Article history:}

Received Dec 31, 2018

Revised Mar 27, 2019

Accepted August 29, 2019

Keywords:

ADDIE,

Camtasia Software,

Learning Media,

Mathematical Comprehension,

Numeral Material

\begin{abstract}
Mathematics is one very important lesson. If students have difficulty in solving mathematics, this supports the ability to communicate a mathematical idea. Students must understand mathematics well. This study aims to determine the feasibility of learning media in the form of videos used camtasia software on numeral material based on mathematical understanding using the $\mathrm{R}$ and $\mathrm{D}$ methodology with ADDIE models. The research instrument used is a practicality questionnaire, an interview questionnaire and validation sheet. From the results of interview questionnaires found that students prefer learning with the presence of learning media and the results of teacher interviews found that lack of facilities for using media in the learning process. The instrument of validation questionnaire produce an average score of $85 \%$ so that it can be said that the learning media in the form of videos are very valid and can be used. The instrument of practicality questionnaire filled by nine students with three high-ability, moderatecapable, and low-ability students produced an average score of $86.77 \%$. It can be said that the practice was very high. Based on the results of each instrument, it can be stated that the learning media in the form of CD-shaped videos is practical and can be used.
\end{abstract}

Copyright $@ 2019$ IKIP Siliwangi. All rights reserved.

\section{Corresponding Author:}

Setiyani,

Departement of Mathematics Education,

Universitas Swadaya Gunung Jati,

Jl. Perjuangan No. 02 Cirebon, West Java, Indonesia

Email: setiyani_0401509081@yahoo.com

\section{How to Cite:}

Setiyani, S., Putri, D. P., \& Prakarsa, D. (2019). Designing camtasia software assisted learning media toward students' mathematical comprehension in numeral. Infinity, 8(2), 143-156.

\section{INTRODUCTION}

Mathematical comprehension is one ability that need to have to learn mathematic. That ability is an important foundation for thinking in solving mathematical and real-life problems. Besides that mathematical understanding ability is very supportive for the development of other mathematical abilities such as communication skills, problem solving, reasoning, connection and other mathematical abilities. The problems that require understanding of mathematical concepts have not been optimally mastered by students, such as the weak understanding of one concept with other concepts needed to solve of mathematical problems (Kariadinata, Yaniawati, Sugilar, \& Riyandani, 2019). Students 
must have ability mathematical comprehension as mathematical understanding is a musthave ability and should be developed in each students self. The ability of students' mathematical understanding can be measured based on the indicators. While its level can be seen based on completeness on indicators of mathematical understanding.

But based on the results of observations conducted by researchers there are still indications that students do not have a level of understanding in accordance with the current level of thinking, as experienced by students in MTsN 2 Cirebon in the subject matter Numbers. The source states that students are still not maximal in understanding the concept of addition to fractions as shown in tab 1.

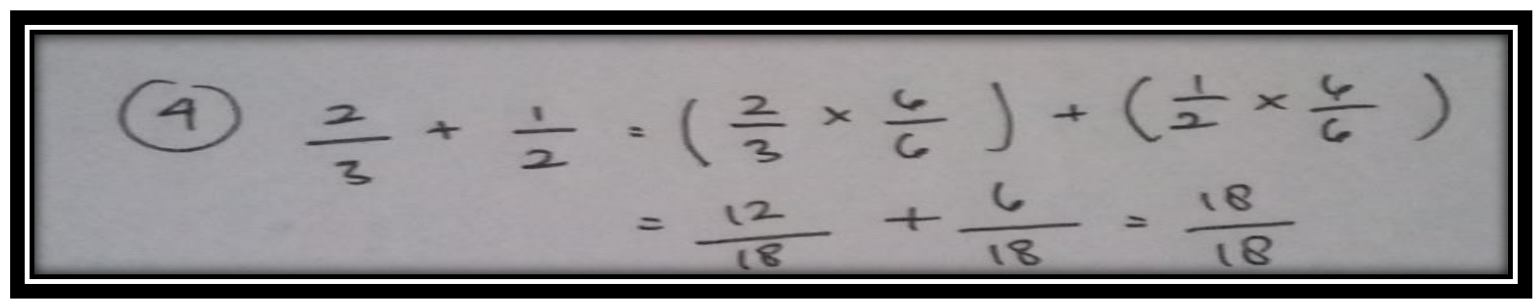

Figure 1. Student Exercise Result

From the operation steps to add the fraction number is correct, that is to look for the Smallest Guild Multiplication (SGM) to equate the denominator, but when determining the numerator $34 \%$ of students are still confused and caused the students' answer to be incorrect.

Students still do not master the concept of multiplication in fractions in operating the multiplication of fractions by simply multiplying the numerator with the numerator and denominator with the denominator. But from $25 \%$ of students' answer above use the steps of the operation of addition or subtraction is by looking for the SGM and equating the denominator. That is what caused student answers less precise as shown in Figure 2.

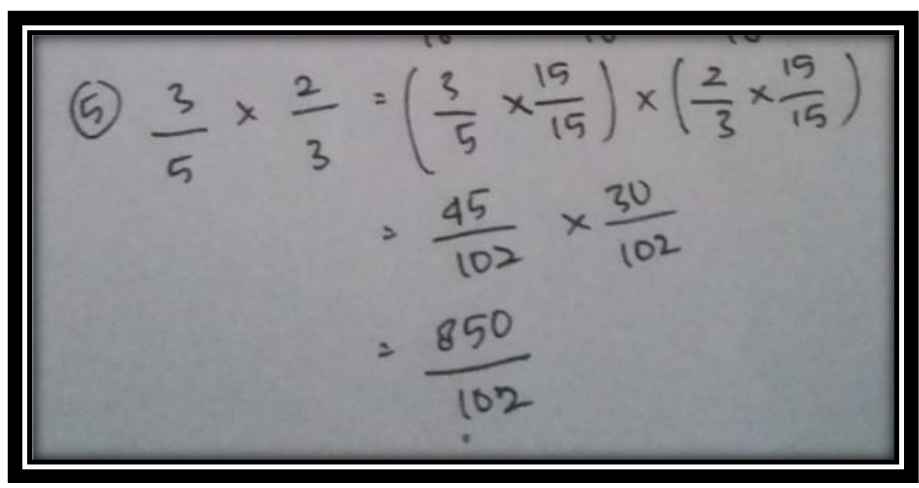

Figure 2. Students who have not mastered the concept of multiplication in fractions.

Students' lack of understanding of the daily problems given related to the subject matter number with the question "Andi is an amateur diver, first practiced diving at a depth of 3 meters uder sea level. After feeling swift diving at a depth of 3 meters, then Andi decided to dive again 7 meters under the sea level. What is the difference in depth in the two conditions, present using a number line! ". Student answers as shown in Figure 3. 


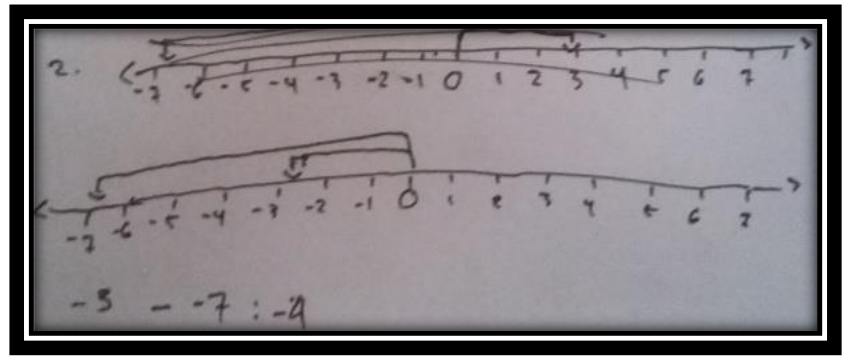

Figure 3. Student who do not understand the mathematical concepts related to indicators change the form of representation to other form.

Figure 3 shows students trying to answer using a number line. But what can be seen in the answers of $47 \%$ of students shows that they lack understanding in using number lines and on the operation, hence students' answers are less precise.

Students also have not been able to identify the properties of a concept related to material numbers with the question "Are commutative and associative properties also valid for integer reduction operations. If yes, show it. If not, explain with an example of a denominator? " Student answers are shown in Figure 4.

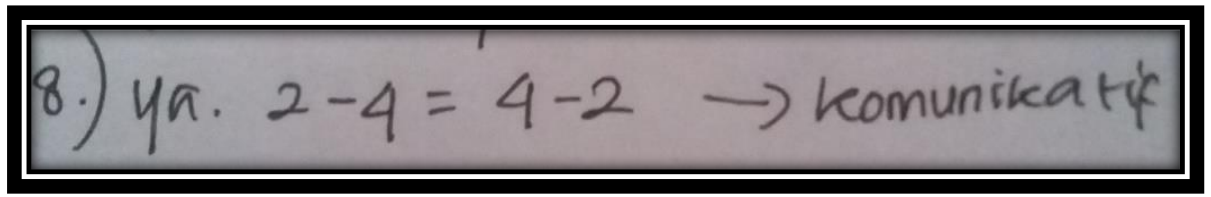

Figure 4. Students who have not been able to identify the properties of a concept

Figure 4 shows the answers of students in proving the properties of a concept in material numbers. In proving the nature of a concept, it must be understood first what communicative properties are and how to prove them. The communicative nature is where $\mathrm{a}+\mathrm{b}=\mathrm{b}+\mathrm{a}$, but what is requested is in the reduction, then the fixed answer "communicative nature does not apply to subtraction, because the result is definitely not the same" so that the answers of $22 \%$ of students above prove a lack of communicative right.

Based on the answers above, it shows that there is still minimal of students' mathematical comprehension ability in MTsN 2 Cirebon. If this fact is ignored, as time goes by this issue can decrease students' interest in learning if, because they feel that mathematics is difficult. Mathematical comprehension ability is the initial ability that must be given as early as possible to students. Based on the results of interviews with several students in VII grade at MTs 2 Cirebon, the researcher found some difficulties that students faced when studying material numbers. $20 \%$ of students stated that they found it difficult when they encountered questions about proving the properties of numbers, as well as the operation of negative summation. In the learning process students express that they are more interest of learning with media and some exercises.

Based on the results of the interview above, the learning process requires learning media as teaching aids in delivering material. Learning materials is very important for teachers and students. It have a major contribution to the success of the learning process is implemented (Noto, Pramuditya, \& Fiqri, 2018). Criticos state that media is one component of communication, namely as a messenger from the communicator to the communicant (Daryanto, 2013). If communication does not go well, the message conveyed by the teacher is difficult for students to understand. Conversely, if communication is 
effective and efficient, more and more learning objectives are achieved. The use of learning media in the teaching process can make students better understand and learn according to their interests and abilities (Kintoko \& Sujadi, 2015). The word media comes from Latin is the plural form of the word medium boundary about the notion of media is very broad, but we limit it to the world of education only, namely the media used as tools and materials for learning activities.

Learning media is very important to be used by teachers in the teaching and learning process. Learning media provide motivation to students in mathematics. With learning media students are more enthusiastic in learning in the classroom. Of course the learning media needs to be created interestingly and designed practically, these aims to provide students with interest and interest in following the teaching and learning process in the classroom. Media Learning CD can be used as an alternative to convey messages by the message giver (teacher) to the recipient (student).

The use of the Learning CD media allows students not only to study at school, but also to learn by themselves at home. Learning CDs have characteristics such as attractive shapes and colours that can increase the activity of students to learn and clarify a concept. So with the use of this media, the learning process will feel more interesting and not boring and will stimulate students to learn mathematics. By using the Learning $\mathrm{CD}$, the contents of the subject matter can be modified using various applications such as Camtasia Studio and Microsoft Power point which can be combined into a more interesting unified learning media. So that it can help teachers in delivering subject matter and can help students understand mathematical concepts. The development of interactive learning CD assisted by camtasia studio software on integer material has been studied before. The feasibility test results are very good and the results of student trials using interactive learning CD using the problem based learning model assisted by camtasia studio software on integer material are better than conventional learning in class VII of the 2nd Middle School in the 2015/2016 (Prasetyawan, 2017).

Based on the description of the background above, the author wants to find out how camtasia software design helps learning media in students' mathematical understanding ability in numeral material? Is the design of learning media assisted by camtasia software on the ability of students' mathematical understanding of material numbers that have been developed practice?

\section{METHOD}

This study uses the R \& D (Reserch and Development) method with the ADDIE model. To compile various systems, both formal and non-formal systems of instructional systems that are often used, namely ADDIE. The ADDIE model is one of the most commonly used models in the field of instructional design to produce effective designs (Aldoobie, 2015). The ADDIE model consists of five stages, namely: Analysis, Design, Development, Implementation, and Evaluation. The complete stages are shown in Figure 5 (Branch, 2009). 


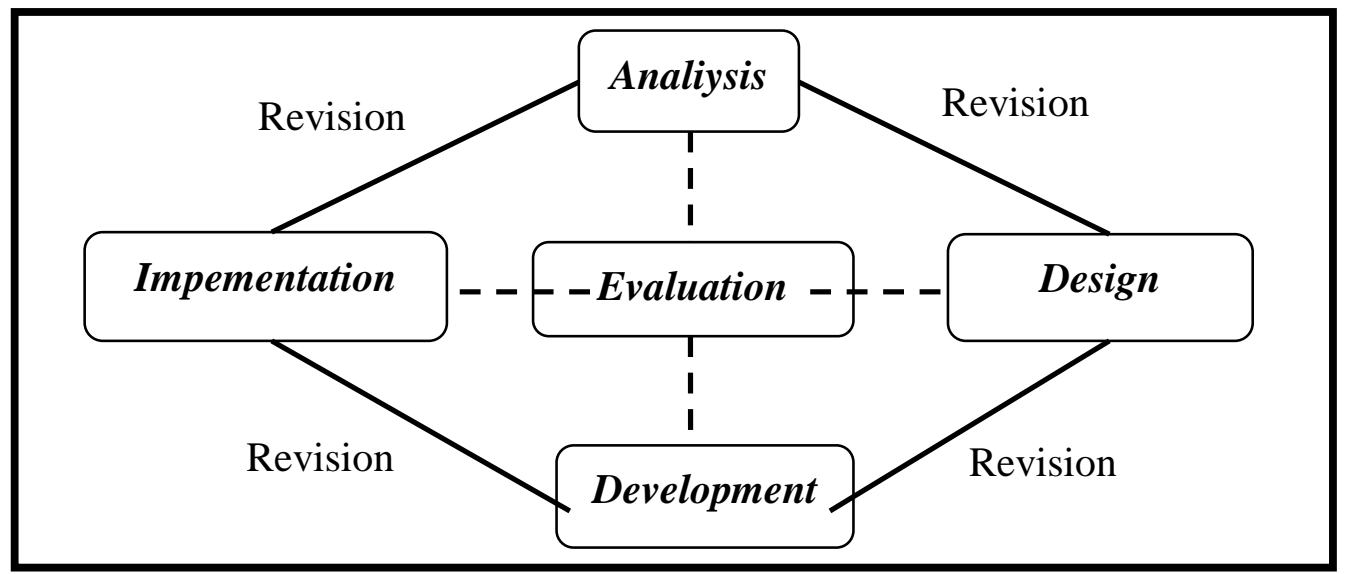

Figure 5. Model ADDIE

The explanation of the ADDIE model which consists of five stages is as follows: The analysis stage consists of two stages, namely needs analysis and identification of needs. At this stage, analysis is carried out to determine the learning needs of students, by conducting a needs analysis, identifying problems, and performing task analysis. Analysis must include learning characteristics, motivation, technological abilities, and learning objectives (Wang \& Hsu, 2009).

The design stage is the stage after learning needs are identified then selecting media and then designing learning media. This stage teaching and learning activities are designed. The activities carried out are formulating competencies determining learning materials, strategies, evaluations, sources and media makers.

The development stage is in the form of making or producing or realizing a product specification learning that has been determined by the design resistance. In this phase the researcher builds and develops with the help of media software and supporting documentation (Muruganantham, 2015). Besides that at this phase also began to make examples of real products and good designs (aldoobie, 2015). After the product is produced the next step is validating the product by experts.

The implementation stage is the stage of utilizing or using learning products in learning activities. Activities that need to be prepared include preparing classrooms, schedules, tools and media, preparing students physically and mentally. The purpose of this phase is to convey or promote product results to students on the material and learning objectives (Muruganantham, 2015).

The evaluation stage is a process to see whether the learning system that is being built is successful, in accordance with initial expectations or not. To find out this, an evaluation of the product has been made with the aim to find out whether students can immediately understand the material or competencies taught in class. The results of this evaluation are used to provide responsiveness or opinion to the product maker. This ADDIE model provides an opportunity to evaluate activities at each stage. The modified research flow that the author did can be seen in Figure 6. 


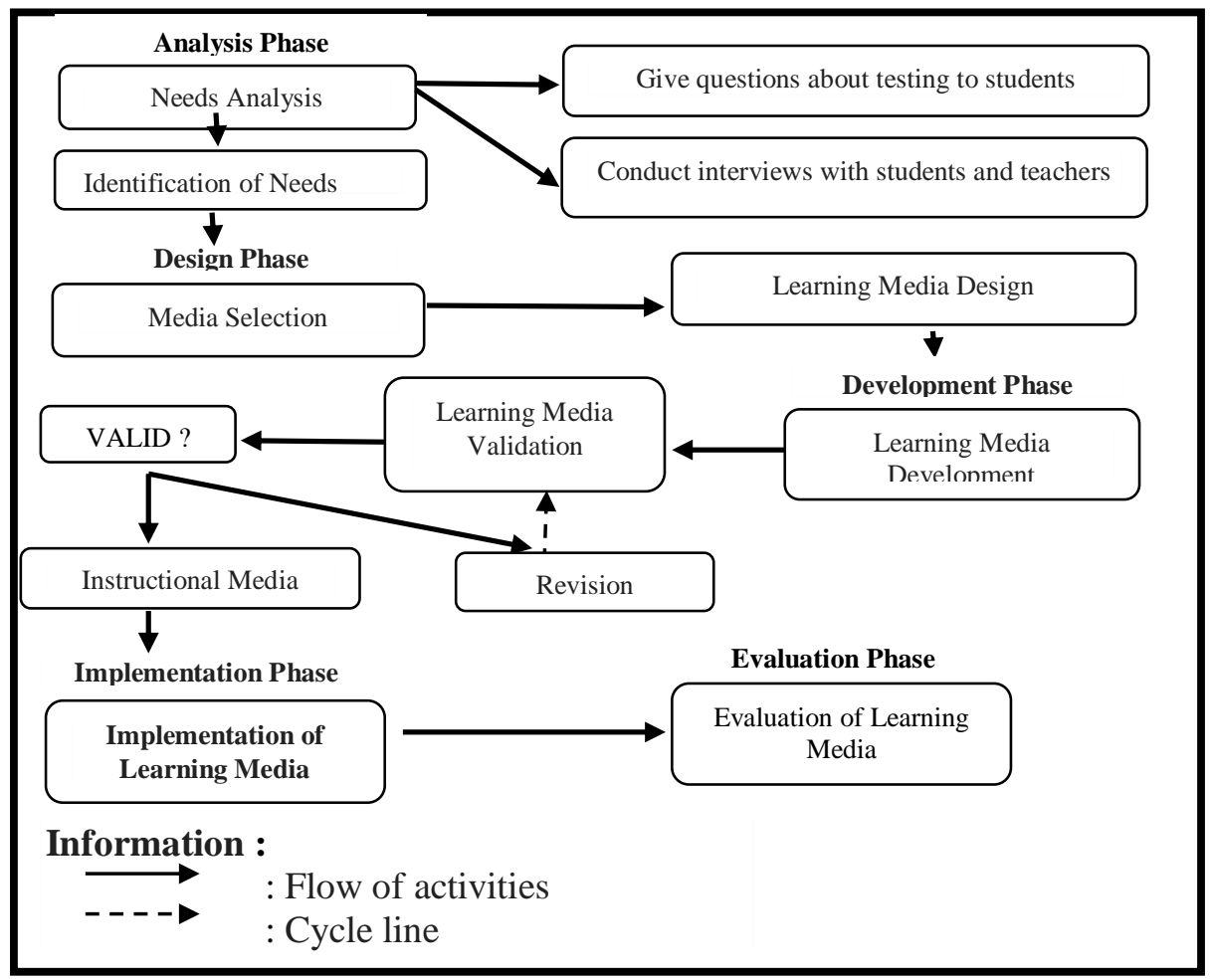

Figure 6. ADDIE Research Flow

\section{RESULTS AND DISCUSSION}

Learning media design carried out by researchers has some stages, namely analysis, design, development, implementation and evaluation which will be presented by the researcher as follows.

\subsection{Analysis Phase}

Analysis is the initial stage carried out by researchers in the process of making learning CDs. This stage is used to find out the learning needs and difficulties experienced by students during the learning process in material numbers. This stage consists of two activities namely needs analysis and identification of needs. The two activities will be presented as follows:

\subsubsection{Needs Analysis}

Needs analysis is a way of knowing student learning difficulties and what are needed by students in the teaching and learning process. At this stage the researcher analyzes the needs of students by conducting interviews and giving questions about the test of mathematical abilities in the material numbers. Interviews were conducted to the mathematics teachers and some seventh grade students at MTs Negeri 2 Cirebon to find out the opinions of teachers about the difficulties experienced by students and how teachers overcome learning difficulties and know the opinions of students regarding the teaching and learning process in popular classes and difficulties experienced by students. Student test results on number material show that students are still not maximal in understanding the concept of addition of fractions, the concept of multiplying fractions, solving problems in daily life, and not being able to identify the properties of a concept in numbers material. From the students' interview found some difficulties that students faced 
when learning material numbers. $20 \%$ of students stated that they found it difficult when they encountered questions about proving the properties of numbers, as well as the operation of negative additions. In the learning process students reveal that students are more interest to learn learning media and lots of practice questions. While the results of the interview with teachers found some difficulties experienced by students when studying material numbers. Mathematics teachers at MTs Negeri 2 Cirebon stated that students were still having difficulty in learning number material, it can be seen from the learning evaluation carried out by the teacher there was still many students who got scores under minimum completion criteria. The way to overcome this is by giving practice questions that contain comprehension skills, where comprehension ability is the initial ability that must be possessed by students. The learning process still uses lectures and does not use media in learning related to material numbers.

\subsubsection{Identification of Needs}

At this stage, it is identifying the needs that have been obtained from the results of the trial questions and the results of interviews with students and mathematics teachers. From the needs analysis, several important points are obtained: students are still not maximal in understanding material numbers, the level of students' mathematical understanding ability is still not maximal related to material numbers, learning media have not use in the learning process, and students are more excited about learning with media and lots of practice questions. The results of identification of these needs are used by researchers as a reference in designing learning media for the learning process of students in the classroom.

\subsection{Design Phase}

Design is the second stage carried out by researchers. Based on the identification of needs researchers will design or create learning media that appropriate to the needs and overcome the difficulties experienced by students. At this stage includes activities: collect material references In this activity the researcher makes material by reference to various sources or reference books. Beside compeling material, the researcher also determines the sub-chapter of the material that will be discussed in the learning media created. Based on the results of the analysis phase, the researcher took the sub chapter of integer operating material and the operation of fraction numbers. The material included in the learning media has been adjusted in terms of language and structure to make it easier for students in the learning process. The language used in the preparation of the material is to use polite language according to EYD (Enhanced Spelling), but still easy to understand by students.

As explained in the analysis phase, that in the learning process at MTsN 2 Cirebon class VII related to material numbers has not used learning media and only with lectures. This makes students bored in learning, so researchers are interested in creating learning media that aim to attract interest and provide learning enthusiasm for students in the form of learning videos assisted by camtasia software and produce products in the form of learning CD.

In this activity the researcher designed learning media with the help of camtasia software. The integer material is designed in this stage assisted by camtasia software makes it easier for students to understand each step of the problem solving. besides that this application can be installed via an android phone, so students can study anywhere and anytime. Next is a presentation on the design of learning media design.

Making a camtasia video In the initial stages starts with entering the title of the video. Select the menu to enter the text as shown in Figure 7. 


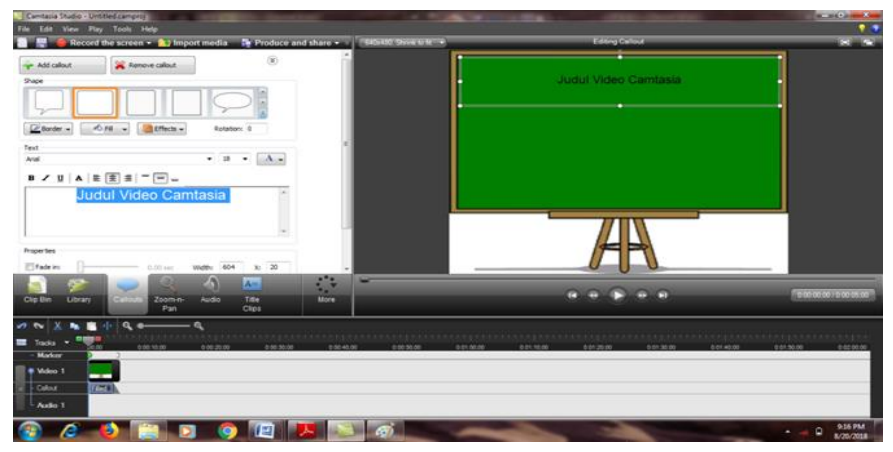

Figure 7. To write text

From this step, the researcher will start assembling and designing operating material with a round and fraction operation. The following page is for entering material text in the camtasia video setup (Figure 8).

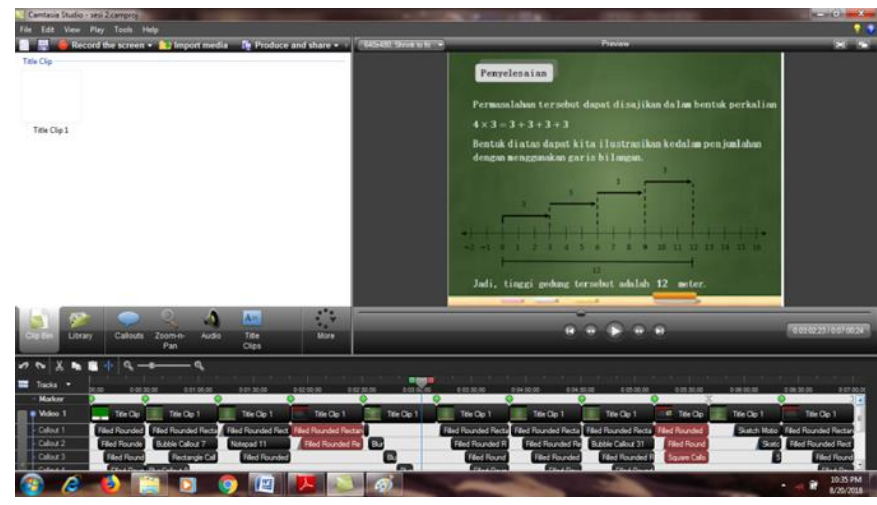

Figure 8. Includes material text

In compiling the flow of activities in the camtasia video researchers also pay attention to the material, examples of questions and practice questions must be in accordance with the initial objectives of making learning media assisted by camtasia software towards mathematical understanding skills.

The following are the design results that the researchers made, namely the video camtasia with integer operating material and fractional number operations on mathematical comprehension abilities for class VII junior / MTS students. The following is the display made by the researcher:

\subsubsection{Making slides}

In making the initial slide, the researchers made several slides. The slide is the opening, an explanation of KI (Core Competence) and KD (Basic Competence), an explanation of mathematical indicators, indicators of mathematical understanding and learning objectives. The purpose of the slides is to make the teacher or students loyal to the media know the goals that must be achieved by the students and the contents of the video.

\subsubsection{Making material slides}

In making the material slide the researcher is include integer operating material and fractional number operations in the camtasia video. The content of the material is in the form of an explanation of each sub chapter of the material number. the material that will be 
presented are integer addition operations, integer reduction operations, integer multiplication operations, integer division operations, fraction operations with fractions, fractional reduction operations, fractional multiplication operations, and fraction division operations.

\subsubsection{Making sample slides of questions along with discussion and understanding ability test exercises}

In making examples of questions, the researcher encloses discussion and problem training. It is intended that students understand from each example of the problem given. The placement of each sample slide is given directly after an explanation of each material.

\subsubsection{Making the final slide}

This slide contains the closing of the camtasia video by providing motivation for students, and the biodata of the maker

\subsection{Development Phase}

This stage is the third stage carried out by researchers. At this stage the researcher embodies the design into a product in the form of a CD learning. To create the product there is a development where the results of the video learning design in the Camtasia software are converted into MP4 by clicking produce and share then select HD so that the quality is good then next as shown in Figure 9.

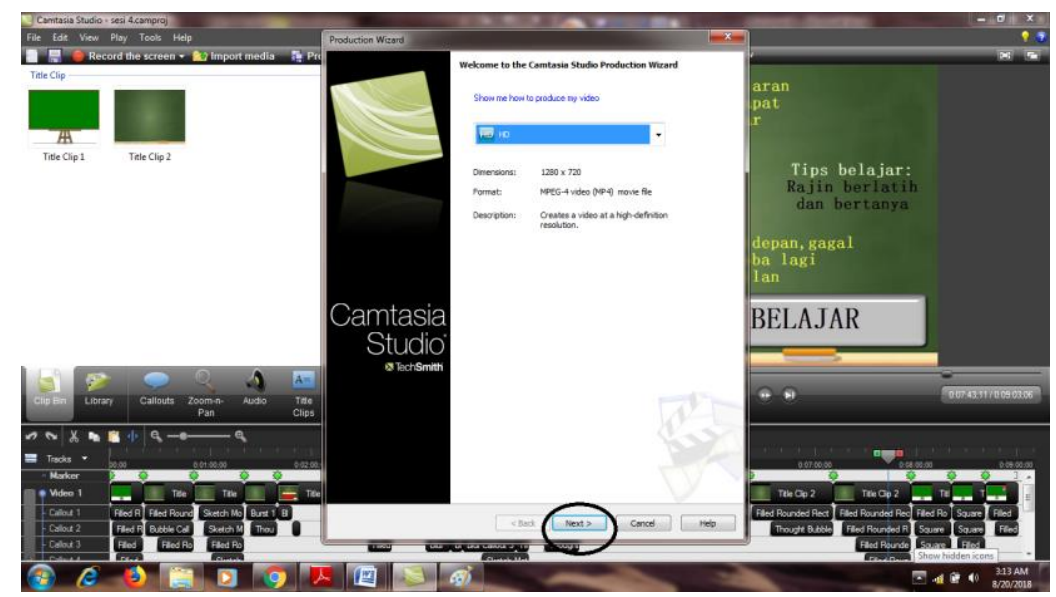

Figure 9. Changing to MP4

After MP4 learning videos are created, the next step is burning the MP4 video into a CD / DVD that has been prepared to become a learning CD. When it has turned into a learning $\mathrm{CD}$, it is then continued to the learning $\mathrm{CD}$ validation stage that has been made. The goal is to find out whether the product is valid or not. In the validation stage this learning $\mathrm{CD}$ was validated by three mathematics lecturers and one mathematics teacher. The last step in making a valid learning $\mathrm{CD}$ is to test the validity level of the learning CD. This stage aim to find out whether the learning CD is worthy of use or not. Validation used is an assessment in the form of a questionnaire. The validator consists of three mathematics lecturers at Swadaya Gunung Jati University and one mathematics teacher at MTsN 2 Cirebon. 
This validation is done to find out whether the product created by the researcher is valid or not. Based on the results of validation that each validator provides a good assessment of the learning CD produced. This is the result of the overall assessment which is quite high with the acquisition of results about 62 to 72 from a maximum score of 80 . The next step that must be done is to analyze the data. Data analysis will be divided into two stages, namely the analysis of validation data for each validator and overall data analysis. Recapitulation of analysis calculations from each validator as shown in Table 1.

Table 1. Recapitulation of each Validator

\begin{tabular}{cccc}
\hline Validator & Score achieved & $\begin{array}{c}\text { Expected } \\
\text { maximum score }\end{array}$ & $\begin{array}{c}\text { Overall validation } \\
\text { criteria (\%) }\end{array}$ \\
\hline V-1 & 68 & & 85 \\
V-2 & 62 & 80 & 77.5 \\
V-3 & 72 & & 90 \\
V-4 & 70 & & 87.5 \\
\hline \multicolumn{2}{r}{} & Average & 85 \\
\hline
\end{tabular}

Based on the calculation of the analysis results from each validator, it has been obtained for $\mathrm{V}-1=85 \%$ (very valid), $\mathrm{V}-2=77.5 \%$ (quite valid), $\mathrm{V}-3=90 \%$ (very valid), and V-4 $=87.5 \%$ (very valid). This shows that there is one validator who gives an evaluation with sufficiently valid criteria and there are three more validators who provide very valid criteria. so based on these assessments the resulting learning $\mathrm{CD}$ can be used.

Overall Validation Then the overall analysis calculation is done to find out that this learning CD is valid or not. The following formula will be used.

$$
\begin{aligned}
V_{\text {combined }} & =\frac{85 \%+77.5 \%+90 \%+87.5 \%}{4} \\
V_{\text {combined }} & =\frac{340 \%}{4}=85 \%
\end{aligned}
$$

Based on the results of these calculations, obtained for $\mathrm{V}$-combined $=85 \%$. Furthermore, the calculation results are interpreted with the following criteria (Table 2).

Table 2. Validation criteria

\begin{tabular}{cl}
\hline Validation criteria & \\
\hline $85 \% \leq \mathrm{V} \leq 100 \%$ & Very valid or can be used without revisions \\
$70 \% \leq \mathrm{V}<85 \%$ & It is quite valid or can be used but needs to be small revisions \\
$50 \% \leq \mathrm{V}<70 \%$ & $\begin{array}{l}\text { Less valid, it is recommended not to be used because it needs major } \\
\text { revisions }\end{array}$ \\
$\mathrm{V}<50 \%$ & Invalid or may not be used \\
\hline
\end{tabular}

Based on the validation criteria, the assessment of the validator is V_combined = $85 \%$ included in very valid criteria.

\subsection{Implementation Phase}

The implementation phase is the fourth stage. At this stage the researcher carried out the implementation of the product created in the form of a mathematics learning $\mathrm{CD}$ at 
MTs 2 Cirebon. The implementation of a mathematics learning CD is using the Talking Stick model with a scientific approach. In the core learning process, the researcher explained the material about summing operations and reduction by round using learning media in the form of videos. After explaining the researcher also gave an example of a question along with explaining how to solve the sample problem and the student observing then giving the question what the students did not understand. When the question and answer process between researchers and students is completed and students understand what is conveyed by the researcher, then the researcher gives questions to students and prepares music and sticks. Students do exercises on the questions given by the researcher individually. The researcher does a talking stick game to test students' mathematical abilities. For students who get a section to discuss the questions the researcher cooperates with the answers that have been obtained. After the game is finished the students record all the answers that have been answered with the talking stick game. At the end of the implementation the researcher gave a brief explanation and gave conclusions and offered to students if they wanted to have a learning video, they could copy paste or share it to PC / Handphone. Before implementation, the researcher gave a practical questionnaire to students which aimed to find out the practicality of the learning CD.

\subsection{Evaluation Phase}

The evaluation phase is the fifth stage. At this stage the researcher asks for input from the teacher and the students that aimd to find out whether the learning media in the form of video learning $\mathrm{CD}$, can overcome student learning difficulties in material numbers and realize the desired needs of students in the learning process. Judging from the students' answers and the input of teachers and students that with the use of learning CDs in the learning process in the classroom can overcome students' learning difficulties in material numbers and give enthusiasm to students in the learning process. This shows that by making learning media in the form of learning vide in CDs can overcome the difficulties of students in understanding material numbers and realizing the needs of students in the learning process.

After five stages, the researcher then processes the practical data that is filled in by the students at the implementation stage. The data is in the form of quantitative data. Practicality is used to find out the products produced, namely learning media in the form of mathematical learning CDs in the form of videos that are practical or not used in the learning process in mathematics subjects with sub chapter numbers in addition, subtraction, multiplication, integer division and fraction numbers. Based on Table 3, it appears that each assessor gives a good assessment of the learning CD produced. This is the result of a high overall assessment with yields around 26 to 31 from a maximum score of 32. The next step that must be done is to analyze practical data. It aims to find out the scores obtained from each assessor so that they can formulate practical criteria or not. Recapitulation of analytical calculations from each assessor as shown in Table 3.

Table 3. Recapitulation of analysis calculations from each assessor

\begin{tabular}{ccc}
\hline Assesor (P) & Score achieved & $\begin{array}{c}\text { Overall Assessment } \\
\text { Criteria (\%) }\end{array}$ \\
\hline P-1 & 29 & 90 \\
P-2 & 31 & 96 \\
P-3 & 30 & 93 \\
P-4 & 28 & 87
\end{tabular}


Setiyani, Putri, \& Prakarsa, Designing camtasia software assisted learning media ...

\begin{tabular}{ccc}
\hline Assesor $(\mathbf{P})$ & Score achieved & $\begin{array}{c}\text { Overall Assessment } \\
\text { Criteria (\%) }\end{array}$ \\
\hline P-5 & 28 & 87 \\
P-6 & 29 & 90 \\
P-7 & 27 & 84 \\
P-8 & 26 & 81 \\
P-9 & 27 & 84 \\
\hline Average & & 97.66 \\
\hline
\end{tabular}

Expected maximum score $=32$

Tabel 3 shows that the assessment of all students with criteria is very practical. As the result based on the assessment the learning CD produced is practical. Mathematics learning is done very much. one of the learning media development approaches with rectangle-based geographic post problems. After learning is done using this media, this media can facilitate students in asking about the characteristics of getting a quadrilateral, facilitating students to learn the relationship between the types of building rectangles that have the same nature, and provide opportunities for teachers to conduct discussions about mathematical communication students when asking and writing (Saputro, 2016). The results of the research carried out have the advantages of the research conducted by Latif, Darmawijoyo, \& Putri (2013) which produced a product from the camtasia software in the form of videos that were learned through edmodo and the learning process needed the internet, different from what the researchers produced. Learning process does not require an internet connection. The disadvantage of learning media that uses camtasia software is not the availability menu equation. Thus it was developed on mathematical subjects that use formulas - difficult to use.

\section{CONCLUSION}

Making learning media with software aided by camtasia on the ability of students' mathematical understanding of material numbers that have been completed, this is proved by each example and practice about the problem of the ability to access understanding. And in the learning process using learning media consisting of learning CDs that make students more enthusiastic in learning and more practical for students because the created learning CD contains videos that can be used anywhere both on PC / Hanphone, so students can learn everytime students want. Assessments of products produced by researchers by experts indicate that learning is made very valid, with a presentation of $85 \%$. It can be deny that learning CDs can be used by students. Practicality of learning CD media conducted by nine students consisting of three high abilities, three moderate abilities, and three low abilities. Based on the results of nine seventh grade students at Mts Negeri 2 Cirebon who are capable of high, medium and low shows that the learning CD produced is very practical, with presentations of $97.66 \%$. It is important to state that the learning $\mathrm{CD}$ is very practical for learning class VII students in material numbers. Suggestions that researchers can convey based on the results of research in the framework of making mathematics learning CDs are firstly in the process of implementing media learning CDs in the form of videos do not use a projector (infocus), so each student must have the video. Secondly, in evaluating the questions there needs to be a more diverse question additionhe Conclusion should contain the confirmation of the problem that has 
been analyzed in result and discussion section. The Conclusion should contain the confirmation of the problem that has been analyzed in result and discussion section.

\section{REFERENCES}

Aldoobie, N. (2015). ADDIE model. American International Journal of Contemporary Research, 5(6), 68-72.

Branch, R. M. (2009). Instructional design: The ADDIE approach (Vol. 722). Springer Science \& Business Media.

Daryanto, D. (2013). Media Pembelajaran: perannya sangat penting dalam mencapai tujuan pembelajaran. Yogyakarta: Penerbit Gava Media.

Kariadinata, R., Yaniawati, R. P., Sugilar, H., \& Riyandani, D. (2019). Learning motivation and mathematical understanding of students of islamic junior high school through active knowledge sharing strategy. Infinity Journal, 8(1), 31-42.

Kintoko, K., \& Sujadi, I. (2015). Pengembangan Media Pembelajaran Matematika Berbantuan Komputer dengan Lectora Authoring Tools pada Materi Bangun Ruang Sisi Datar Kelas VIII SMP/MTs. Jurnal Pembelajaran Matematika, 3(2).

Latif, Y., Darmawijoyo, D., \& Putri, R. I. I. (2013). Pengembangan Bahan Ajar Berbantuan Camtasia pada Pokok Bahasan Lingkaran melalui Edmodo untuk siswa MTs. Kreano, Jurnal Matematika Kreatif-Inovatif, 4(2), 105-114.

Muruganantham, G. (2015). Developing of E-content package by using ADDIE model. International Journal of Applied Research, 1(3), 52-54.

Noto, M. S., Pramuditya, S. A., \& Fiqri, Y. M. (2018). Design of learning materials on limit function based mathematical understanding. Infinity Journal, 7(1), 61-68.

Prasetyawan, A. (2017). Pengembangan cd pembelajaran interaktif dengan menggunakan model problem based learning berbantuan software camtasia studio pada materi bilangan bulat. AKSIOMA: Jurnal Matematika dan Pendidikan Matematika, 7(1), 26-35.

Saputro, B. A. (2016). Learning media development approach with a rectangle problem posing based geogebra. Infinity Journal, 5(2), 121-130.

Wang, S. K., \& Hsu, H. Y. (2008). Using ADDIE model to design second life activities for online learners. In E-Learn: World Conference on E-Learning in Corporate, Government, Healthcare, and Higher Education, 2045-2050. 
